\title{
The Potrait of Race Amalgamation in the Movie of Guess Who Directed by Kevin Rodney Sullivan
}

\author{
Ahmad Irfan Fauzi ${ }^{1}$, Abdul Basid ${ }^{2}$ \\ ${ }^{1,2}$ Universitas Islam Negeri Maulana Malik Ibrahim, Jalan Gajayana No 50 Malang, Indonesia
}

\{16310100@student.uin-malang.ac.id ${ }^{1}$, abdulbasid@bsa.uin-malang.ac.id $\left.{ }^{2}\right\}$

\begin{abstract}
The amalgamation is a mix between two persons who have different ethnicity. The amalgamation in general is caused by social interaction, migration, and assimilation. The amalgamation has an impact on the survive of ethnic or its extinction. One of the movie that described the amalgamation is Guess Who directed by Kevin Rodney Sullivan. This study means to elaborate the amalgamation, its cause and its impact on society in the movie of Guess Who directed by Kevin Rodney Sullivan. The kind of this research is a descriptive qualitative research. The data source is the movie of Guess Who. The techniques of data collection that used by the researchers are watching, reading, and noting. The techniques of data analysis consist of three steps. They are reducing the data, displaying the data, and drawing conclusion. The results of this study are: (1) the kind of amalgamation in the movie of Guess Who are wedding and social interaction; (2) the cause of amalgamation in the movie of Guess Who are love and the same intention and need; and (3) the impacts of the amalgamation toward society in the movie of Guess Who is open minded society, respect among member of society, and the lack of labelling white and black.
\end{abstract}

Keywords: amalgamation, black people, movie, white people.

\section{INTRODUCTION}

Nowadays the amalgamation becomes interesting topic, not as it used to be when in 1967, between white race and black race in America, racial and ethnic inequality occurred. Even up to legislation, the phenomenon regulates the prohibition of mixed marriage amalgamation. However, over time until now mixed marriage is no longer something that violates the law [1].

Amalgamation is a social process that merges two cultural groups into one, which in turn gives birth to something new. Amalgamation will clearly eliminate the conflicts in the group. An example of a historical treasure is the contradictions between the Anglo-Saxon and Normandy tribes that ended when there was a mixed marriage between the two ethnic groups. Mixed marriages between the two large groups have given rise to a successful amalgamation process [2, p. 64].

Amalgamation according to Schaefer is that merging occurs when the majority and minority groups join in forming a new group [3, p. 287]. Whereas according to Suhardi and Sri Sunarti that amalgamation is the biological mixing process of two groups of humans, each of which has different physical characteristics [4, p. 216]. In contrast to Bruce J. Cohen, amalgamation is a 
marriage between groups different groups. The result of this process is the emergence of the descendants of new individuals with different physical characteristics [5, p. 368].

We can find amalgamation from various kinds, one of them in racial groups. In general, this racial group consists of three types namely Caucasian race (white skin), Negroid race (black skin), and Mongoloid race (yellow skin) [5, p. 362]. Race groups can relate to each other in various ways ranging from mixed friendship and marriage to hostility, and from behaviors that require mutual agreement to behavior imposed by the dominant group [6, p. 288].

The existence of racial groups is not always permanent and is often lost due to amalgamation. Each of them has their own characteristics. Although these different physical features rarely disappear completely, but we difficulty find a large group of individuals who are a "genuine" type of race group [7, p. 63].

In relation will the amalgamation there is a movie that describes amalgamation between white race and black race. It is "Guess Who" movie, that directed by Kevin Rodney Sullivan, and a 2005 American comedy. The movie focuses on black women who are married to white men and this movie is one of the American Box Office with revenues of 101 million dollars.

In the context of amalgamation studies, the researchers find some studies. They are: (1) Kardiyan elaborated half a century of amalgamation between Javanese ethnic and local ethnicity in Siabu Village, Salo District, Kampar Regency [8, p. 1]; (2) Isma described amalgamation between Betawi ethnic residents and Chinese in Gunung Sindur District, Bogor Regency [9, p. xi]; (3) Pepizon explained amalgamation relationship in multi-cultural society in Batang Merangin District, Kerinci Regency, Jambi Province [10, p. ix].

Based on the above explanation and considering studies describing amalgamation, the researchers aim to reveal the forms of racial amalgamation, the causes of appearing racial amalgamation, and the impacts of racial amalgamation towards society.

\section{METHODOLOGY}

There are several characteristics of qualitative research characteristics in general. They are: (a) natural settings as direct data sources and researchers as key instruments; (b) descriptive; (c) prioritizing results rather than processes; (d) inductive data analysis; e) meaning or meaning is the main concern [11, p. 27]. This research is qualitative research because it describes racial amalgamation in the movie "Guess Who" directed by Kevin Rodney Sullivan. Qualitative research is research that solves the problem using empirical data [12, p. 20].

Data needed in research can be collected from various data sources [13, p. 29]. The primary data sources is the movie "Guess Who" directed by Kevin Rodney Sullivan [14]. While secondary data sources are books, articles or journals related to racial amalgamation theory. The techniques of data collection used are watching and taking a note technique. The researchers themselves are a key instrument both in data collection and data analysis $[15, \mathrm{pp}$. 15-16].

The data validation technique uses a three-stage creativity test. They are: (1) increasing perseverance [16, pp. 133-134]. In this step, the researchers ascertain the findings about the kinds of amalgamation, their causes, and their impact towards family and society is correct by reading amalgamation theory and watching movie; (2) Triangulation consists of several types, among them are triangulation of sources, data, experts, and time. Whereas in this study researchers used source and data triangulation [17, p. 273]. In this step, the researchers ensure that data source used, theory used, and techniques used are correct; (3) discussions with friends and expert [18, p. 67]. In this step, the researchers discuss findings and interpretations of findings with friends and expert to make them correct, detailed, and comprehensive. 
Technique of data analysis used in this research is the Miles and Hubermann model which consist of three steps. They are data reduction, data presentation, and conclusions drawing [19, p. 32]. The step of data analysis begins with preparing and organizing data. They are transcripts or image data such as photos to be analyzed, then reducing the data into themes through the coding and summarizing process, and finally presenting data in the form of charts, tables, or discussions [20, p. 251].

\section{FINDINGS AND DISCUSSION}

\subsection{Kinds of Amalgamation}

In this sub-theme, the researchers find that the kind of amalgamation contained in the movie "Guess Who" directed by Kevin Rodney Sullivan is marriage and social interactions. As described in the following table:

\begin{tabular}{ll}
\hline \multicolumn{1}{c}{ Table 1. Kinds of Amalgamation } \\
\hline Kinds & Findings \\
\hline Marriage & There was a merger caused by planning a marriage \\
& between Caucasian and Negroid race. \\
Sosial interactions & The existence of a marriage plan so that the caucasian \\
& race mingles with the Negroid race then social \\
& interactions occur.
\end{tabular}

Based on the table above, the kinds of amalgamation found in movies Guess Who are marriage and social interaction. Amalgamation in the kind of marriage is usually in the kind of mixed marriages, unlike in 1967 there was a marriage between white and black people in America. Mixed marriages are prohibited and laws that regulate the prohibition of mixed marriages are made. However, at the time the amalgamation was very warmly discussed as an example of the marriage of Indonesian people with Caucasians namely Nur Khamid and Polly Alexandrea Robinson in December 16, 2018. Why can a white race with blacks marry a mixture? Because they were initially based on intense social interaction. As in the following conversation quote:

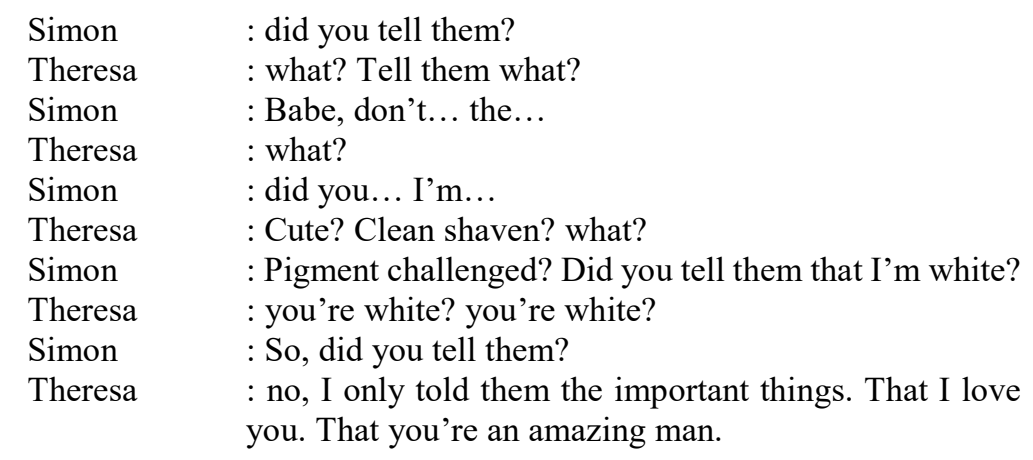

Based on some of the conversations above, there is a racial gap between the white race group and the black race. We can describe in the conversation that the white race is afraid and not ready to mingle with the black race in 1967 in America. Like in the following conversation quote (Kevin Rodney Sullivan, 2005, at 13:06): 


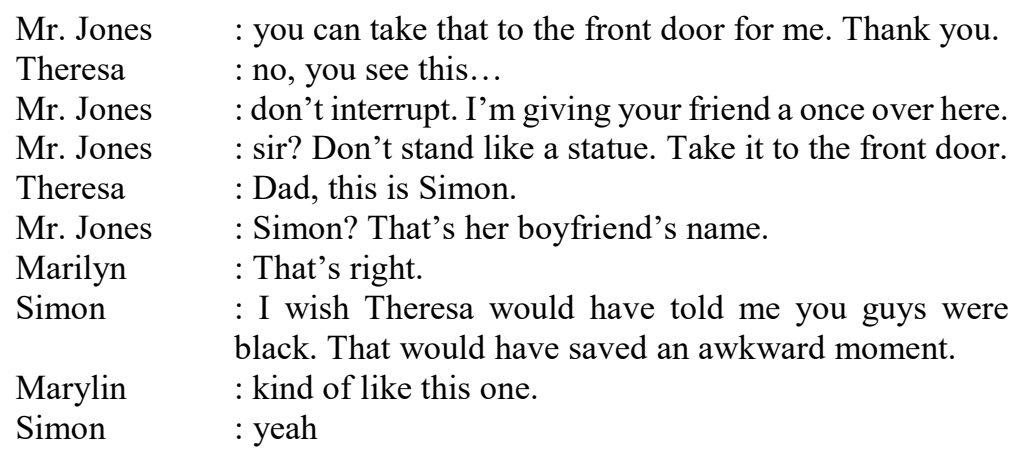

We can see from some of the quotations above that there is racial amalgamation, which is between the Caucasians and the Negroid race. A black father was shocked when he learned that his future daughter-in-law was from a Caucasian (white) race. It was also told in the movie that the black race initially did not like the white race (Caucasian). Then, the white race was ostracized not to stay at home, then looked for a hotel for the accommodation of the Caucasian, as in the following conversation quote:

\begin{tabular}{|c|c|}
\hline Mr. Jones & : I don't like him. \\
\hline Theresa & $\begin{array}{l}\text { : and I really don't think the whole racial thing matters } \\
\text { to him. }\end{array}$ \\
\hline Mr. Jones & : it's not that he's white. \\
\hline Marylin & : it's not? (Kevin Rodney Sullivan, 2005, jam 18:59). \\
\hline Keisha & : Dad, Theresa's boyfriend is white. \\
\hline Mr. Jones & : I know. \\
\hline Keisha & $\begin{array}{l}\text { : I know you know. I just wanted to see your face when } \\
\text { you heard it again. }\end{array}$ \\
\hline Mr. Jones & : Not now. (Kevin Rodney Sullivan, 2005, jam 22:06). \\
\hline Simon & : what are three things that a black man can't get? \\
\hline Mr. Jones & : what is that he can't he get? \\
\hline Simon & : a black eye, a fat lip, and a job. \\
\hline Grandpa & $\begin{array}{l}\text { : I tell you I'm going to kick this boy's ass! (Kevin } \\
\text { Rodney Sullivan, 2005, jam 50:40). }\end{array}$ \\
\hline
\end{tabular}

Based on some of the quoted conversations above, black racial groups are those who like and some who dislike the Caucasian racial group. As will be explained later the causes of amalgamation are based on mutual interest in different races.

\subsection{Causes of Amalgamation}

In this sub-theme, researchers find that the cause of amalgamation found in movie "Guess Who" directed by Kevin Rodney Sullivan's is an interest in other races, a heterogeneous social environment, and intense interactions with different races. In this movie, there is interest or mutual love between Caucasian race and Negroid race. Whereas in the social environment tells 
in the movie "Guess Who" this departs from interest in other races, so the Caucasian race tries to blend and familiarize themselves with the social environment of the Negroid race. Then there are intense interactions that cause racial amalgamation. As described in the following table:

Table 2. Causes of Amalgamation

\begin{tabular}{ll}
\hline \multicolumn{1}{c}{ Causes } & \multicolumn{1}{c}{ Findings } \\
\hline Interest in other races & $\begin{array}{l}\text { There is interest or love for each other between } \\
\text { Caucasians against the Negroid race. }\end{array}$ \\
$\begin{array}{l}\text { Heterogeneous social } \\
\text { environment }\end{array}$ & His daily life in a different race environment. \\
Intense interaction & Frequent interactions with different races. \\
\hline
\end{tabular}

The table above illustrates that the causes of amalgamation are inseparable from the mutual attraction or mutual love for each other, between the Caucasian race and the Negroid race. The social environment is very influential in the merging of the two different races, a new culture will emerge, even one or a new community group. Like the following conversation quote:

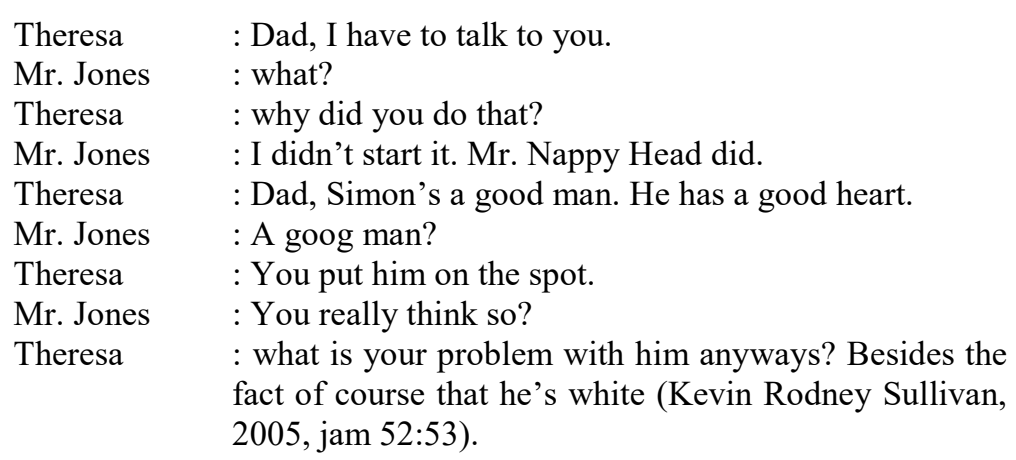

The cause of racial amalgamation is the factor of attraction to other races. There is alone among Caucasian races with Negroid race. Therefore, it cannot be denied that one of the factors causing this amalgamation is the different mutual interests of race. Race groups can also relate to each other in various ways, both friendship and marriage mixed up to hostility and from behavior that requires mutual agreement to behavior imposed by the majority group [6, p. 288].

\subsection{Impact of Amalgamation}

In this sub-theme, researchers find that the impact of amalgamation occurs because of several causes. They are open minded, respect each other and lack of labelling as described in the following table:

Table 3. Impact of Amalgamation.

\begin{tabular}{ll}
\hline \multicolumn{1}{c}{ Impact } & \multicolumn{1}{c}{ Findings } \\
\hline Open minded & open minded community. \\
Respect & respect among community members. \\
Lack of labelling & lack of white and black leather labels. \\
\hline
\end{tabular}


Racial differences in the movie does not describe the racial gaps of the past 1967. The impact of amalgamation in the film Guess Who is open-minded, respect among members of the community, and lack of labeling of blacks and races white skin. As described in the following conversation quote:

$\begin{array}{ll}\text { Mr. Jones } & \begin{array}{l}\text { : I think I forgot what love is until you and Simon } \\ \text { showed up. } \\ \text { : you' 'ill never find. It'll take end of all time. Someone } \\ \text { who understands you. Like I do. }\end{array} \\ \text { Simon } & \begin{array}{l}\text { : I could probably find a million reasons why we } \\ \text { shouldn't be together. But you know what? I don't care. }\end{array} \\ \text { Simon } & \begin{array}{l}\text { : I don't care either. I love you. } \\ \text { : Ladies and gentlemen it gives me great pleasure to } \\ \text { introduce to you all my future son in law Simon Green. } \\ \text { Mr. Jones }\end{array} \\ \text { Mr. Jones } & \begin{array}{l}\text { : Welcome to the family son. Welcome to the family } \\ \text { (Kevin Rodney Sullivan, 2005, jam 1:34:08). }\end{array}\end{array}$

Racial differences are not a very crucial problem when there is no historical background that underlies those distinctions. When a race has an interest in other races and intense interaction, the two races will have the effect of the amalgamation itself. It is clear in the conversation that the existence of racial groups was not always permanent and often lost due to amalgamation.

\section{CONCLUSIONS}

Based on the above explanation regarding amalgamation, it can be concluded that the results and discussion of this study are: (1) forms of amalgamation in the Guess Who film which is racial amalgamation in the form of marriage and social interaction; (2) the cause of amalgamation in the film Guess Who is romance and has the same needs caused by the attraction of other races, intense interaction, and social environment; and (3) the impact of amalgamation on the community in the film Guess Who is an open-minded community, respect among members of the community, and lack of labelling of white race and black race.

\section{References}

[1] M. Sumiati, „Materiips,“ 9 Nopember 2018. [Online]. Available: https://materiips.com/perbedaan-asimilasi-dan-amalgamasi. [Cit. 1 April 2019].

[2] J. D. Narwoko a B. Suyanto, Sosiologi: Teks Pengantar \& Terapan Edisi Keempat, Jakarta: Prenada Media Group, 2015.

[3] R. T. Schaefer, Sociology, New York: Mc Graw Hill, 2007.

[4] S. S. Suhardi, Sosiologi 2 untuk SMA/ MA Kelas XI Program IPS, Jakarta: Pusat Perbukuan Departemen Pendidikan Nasional, 2009.

[5] B. J. Cohen, Sosiologi Suatu Pengantar, Jakarta: Rineka Cipta.

[6] R. T. Schaefer, Sosiologi Edisi 12, Jakarta Selatan: Salemba Humanika, 2012.

[7] P. B. Horton a C. L. Hunt, Sosiologi: Edisi keenam jilid 2, Jakarta: Erlangga, 1992. 
[8] Kardiyan, „Setengah Abad Amalgamasi antara Etnis Jawa dengan Etnis Tempatan di Desa Siabu Kecamatan Salo Kabupaten Kampar,“'Jom FISIP, zv. II, \%1. vyd.2, pp. 1-14, 2015.

[9] A. Isma, „Amalgamasi antara Warga Etnis Betawi dengan Tionghoa di Kecamatan Gunung Sindur Kabupaten Bogor,“p. xii, 31 Agustus 2015.

[10] Pepizon, „Relasi Amalgamasi dalam Masyarakat Multi Kultural di Kecamatan Batang Merangin Kabupaten Kerinci Propinsi Jambi,“p. ix, 21 January 2009.

[11] Bogdan a Biklen, Qualitative Reseach for Education: An Introduction for Theory and Methods, London: Allyn and Bacon, 1982.

[12] Masyhuri a M. Zaenuddin, Metodologi Penelitian: Pendekatan Praktis dan Aplikatif (Edisi Revisi), Bandung: PT Refika Aditama, 2011.

[13] Widyoko a P. S. Eko, Teknik Penyusunan Instrumen Penelitian, Yogyakarta: Pustaka Pelajar, 2012.

[14] K. R. Sullivan, Režisér, Guess Who. [Film]. Amerika: Katalystfilms Production, 2005.

[15] Aminuddin, Pengembangan Penelitian Kualitatif dalam Bidang Bahasa dan Sastra (Edisi Revisi), Malang: Hiski, 1990.

[16] Raco, Qualitative Research Methods, Jakarta: Grasido, 2010.

[17] Sugiyono, Metode Penelitian: Kuantitatif, Kualitatif, dan R\&D, Bandung: Alfabeta, 2017.

[18] B. Rustanto, Qualitative Research on Social Work, Bandung: Remaja Rosdakarya, 2015.

[19] M. B. Miles, A. M. Huberman a J. Saldana, Qualitative Data Analysis: a Methods Sourcebook (Edition 3), United States of America: Arizona State University, 2014.

[20] J. W. Creswell, Penelitian Kualitatif \& Desain Riset: Memilih di antara Lima Pendekatan (Edisi 3), Yogyakarta: Pustaka Pelajar, 2015. 